\title{
Development of a Language Tourism Village Based on Environmental Ethics and Social Entrepreneurship (A Case Study in Karanganyar Regency, Central Java, Indonesia)
}

\author{
Agung Wibowo ${ }^{1,}$ Dimas Rahadian Aji Muhammad ${ }^{1}$, Eny Lestari $^{1}$ Ravik Karsidi $^{2}$ \\ ${ }^{1}$ Faculty of Agriculture, Universitas Sebelas Maret Jl. Ir. Sutami 36 A, Surakarta, Indonesia \\ ${ }^{2}$ Doctoral Program in Development Exstension, Graduate School, Universitas Sebelas Maret, J1. Ir. Sutami 36 A, Kentingan, \\ Surakarta, 57126, Indonesia
}

\begin{abstract}
Numerous environmental problems have emerged along with the development of tourism villages in various areas of Indonesia. This research aims to discover a concept of sustainable tourism village development, and to describe principles of environmental ethics and social entrepreneurship that are line with global demands. The research uses a qualitative method. The location of the research is the District of Karangpandan in Karanganyar Regency, the first language tourism village in Central Java. Data sources include both primary and secondary data. The data collection techniques were interviews, observation, and documentation. The data analysis included the stages of data collection, data reduction, data presentation, and conclusion. The research results show that the model of developing a language tourism village based on the principles of environmental ethics and social entrepreneurship has been proven to contribute to the success of developing village tourism. The principles of environmental ethics consist of respect for nature, moral responsibility for nature, cosmic solidarity, principle of care and concern for nature, principle of "no harm", principle of living simply and in harmony with nature, principle of justice the principles of environmental ethics inspire stakeholders in preserving the environment. Furthermore, the components of social entrepreneurship include: resources, networking, research and development, packaging, marketing, and branding, Leadership and Entrepreneurship and all that gives inspiration for empowering the surrounding community.
\end{abstract}

\section{Introduction}

Alvin Toffler Alvin Toffler divided the economic wave into three different waves. First, the agricultural wave, second, the wave of an industrial economy, and third, the wave of the information economy. The creative economy will become the next new economic wave for the world, oriented towards innovative ideas and concepts [1-4]. The current wave of globalization that is leading in the digitalization of every sector of development demands the participation of all elements of society. The need for information in this modern era has led to the birth of an information economy or economic activities based on the availability of information or fall into the field of informatics [5, 6]. Departing from these points, community empowerment based on principles of environmental ethics [7,8]. and social entrepreneurship will play a strategic role in the future $[9,8]$.

Numerous environmental issues are arising along with the development of tourism villages in various areas of Indonesia. The sustainable tourism industry is an alternative approach that can improve local living conditions, produce a long-term impact, and encourage sustainable community empowerment [11]. Community empowerment is committed to 5 principles: social justice, equality, human rights, inclusion, and self-determination through collective advocacy [12]. The underlying principle of community empowerment is social activities focused on solving social problems [13-16]. The practice of community empowerment can find solutions to people's problems and needs by improving relations between community members, promoting togetherness, and boosting enthusiasm. The main goal of community empowerment is to advance all aspects of life to achieve prosperity in the community itself [15].

Social entrepreneurship through tourism is exemplified as a market-based strategy that can act as a feasible tool for overcoming social problems potentially created by an industry where the practices of an innovative and alternative tourism industry catalyze sustainable community development [18-20]. Through these creative economic activities, communities must inevitably follow the information technology developments taking place and adapt to the present 
age's developments [21, 22]. If communities shut themselves off from new developments in information technology, they will lack competitive power, which will impact their self-development. Social media marketing can be utilized to establish connections in different areas, which will create good relations and can subsequently be used as a consumer database. The development of a creative economic community will bring into reality a city branding which is the right communication method for establishing a brand in a particular city based on its community entity [23-25]. A creative economy does not emphasize the aspect of daily production quantity but rather on the optimal utilization of existing resources to increase its functional value and sale value. Entrepreneurship is a profession that requires a high level of creative power $[26,27]$. Therefore, the development of a creative economy amid a community will indirectly produce entrepreneurs with expertise in various fields. According to [28], creativity must be founded on a thought pattern that is consistently oriented towards progress with new ideas.

Entrepreneurship is applying creativity and innovation in problem-solving and finding opportunities to improve business [29]. An entrepreneur is a person who can perceive and assess business opportunities and gather the resources needed to take the right, innovative action to increase income [30]. Thus, entrepreneurial endeavours need people with high creativity, strong will and who can maintain their commitment to business enterprises. Business is an endeavour to improve the quality of life and has also been proven to play a significant role in improving the quality of a nation.

The Islamic boarding school (pesantren) is an educational institution in Indonesia that emphasises moral education and where the students (santri) live together in dormitories and study under the guidance of teachers who are known as kiai. As well as being recognized as educational institutions, these Islamic boarding schools are also known for their non-classical method of religious teaching in which a kiai imparts knowledge about Islam to the students, based on holy books written in Arabic [31]. A place may be called a pesantren if it possesses several elements, such as a dormitory, teachers (kiai), students, and a mosque. The mosque is the central point of all the students' activities, from worship to study. In the context of the development of a community economy, Islamic boarding schools function as agents of social change and pioneers for the economic revival of the people, by forming entrepreneur groups, both with other boarding schools and with members of the surrounding community.

Empowerment is an effort to improve community capacity by developing and dynamizing the existing potential in a community [32]. Meanwhile, according to [33, 34], empowerment is an effort to improve the honour and dignity, or in other words, to enable the community to become independent. In this case, empowerment is the effort to build the community's power in the Islamic boarding school (the students and the surrounding community) by encouraging, motivating, and raising awareness about their existing potential and developing it further. Therefore, the entrepreneurial empowerment in this research is the ability to develop innovation and creativity that is different from that of other people and to take every opportunity that presents itself. One of the forms of human empowerment is through mentoring or intellectual and personal human development [35]. According to Eimermann et al. (2017), the stages of community empowerment are awareness, capacity building, and empowerment [36, 37].

In bringing about the empowerment of the creative economy in the Islamic boarding school, several main pillars emerge as the executors of the planned empowerment programs. The three main pillars are the kiai-ulama (religious leaders or teachers), the students (santri), and education. As a leader in the Islamic boarding school environment, $a$ kiai-ulama possesses charisma in the students' eyes. The leadership of the kiai-ulama in an Islamic boarding school is highly unique. It implements a pre-modern system, where the social relationship between the kiai-ulama and the students is built upon a foundation of trust rather than a patron-client status. The students' obedience to the kiai-ulama is primarily because they hope for grace, as understood in the Sufi concept. From the time a boarding school is first built, the kiai must make careful, and thorough preparations, not only of mental aspects but also social and economic aspects, which it is hoped will represent the attitude of entrepreneurship. This is what underlies the concept of economic independence development in the Islamic boarding school institution. Activities for entrepreneurial development in and around the Islamic boarding school have superior value. The aspect that distinguishes them from the development of entrepreneurship with a community component, apart from the Islamic boarding school itself, is that religion is the foundation within the boarding school for all their work. Therefore, the boarding school will produce entrepreneurs whose fundamental traits are honesty, trust, creativity, and reliability in running their businesses [38].

This research focuses on answering the question: how can economic recovery be achieved in a community by empowering a language tourism village based on an approach of principles of environmental ethics and social entrepreneurship? The goal is to explain the community's economic recovery through the empowerment of a productive village with a social entrepreneurship approach. The research was compiled using a narrative method. Concepts were drawn to become the focus of discussion to obtain the result, which shows that the principles of environmental ethics and social entrepreneurship activities impact community empowerment in line with global demands.

\section{2 Research Method}

This research This research is qualitative with a descriptive method conducted in the Language Tourism Village in Karangpandan District, Karanganyar Regency. According to Moleong, qualitative research uses a method of direct interviews to understand the attitudes and behaviour of individuals and groups, in this case using open interviews to analyze and understand the different perspectives of individuals about community empowerment based on environmental ethics and social entrepreneurship [39, 40]. The selection of the research objects was directly related to the focus of the research. The informants chosen were the head of Pakel village, the head of Isy Karima Islamic boarding school, youth leaders, MSME practitioners, and community members participating in the empowerment 
program. Samples were chosen using a technique of purposive sampling by $[37,38]$, where the selection of samples was based on criteria formulated by the researcher, and in this case, as people with an understanding and knowledge about the implementation of the community empowerment program in the language tourism village. These informants were the head of Gerdu village and the head of Pakel village, who were responsible for channelling information and guidance to the community; the head of Isy Karima boarding school, who was the source of the innovation and information about the concept of empowerment; members of the youth organization (karang taruna) and members of the community who contributed to and participated in the empowerment program.

The primary data were obtained from the primary source through in-depth interviews with individuals and observation [43, 44]. The data collection process in this research used face-to-face or direct interviews to obtain complete and in-depth information [44, 45]. The interviewing technique was semi-structured so that the researcher could ask additional questions outside the guidelines to obtain more comprehensive and in-depth data and information [46]. The researcher used a non-participant observation method by visiting the environment around the Islamic boarding school, including homestays, restaurants, and creative economy practitioners, to obtain information by observing the activities among individuals at the research location [44, 47, 48]. Meanwhile, secondary data were obtained from books, journals, and photographic documentation. The data collected was presented in the form of sentences, from which a conclusion was drawn using a technique of analysis [49]. Miles and Huberman use an interactive model. The data reduction involves a process of report writing based on the collected data, which is then reduced to provide a picture of the community empowerment in creating a tourism destination. This is followed by presenting the data, grouping the data to facilitate the researcher's analysis, and drawing a conclusion as the final result. In this research, the researcher tested the validity of data using a triangulation of sources. In source triangulation, the researcher focuses on various data sources at the time of the data collection. Similar or like data can be investigated further using several different data sources [50,51]. Finally, to ensure the accuracy of the data, a conclusion was drawn from the data testing that had already been conducted.

\section{Research Results and Discussion}

The development of a language tourism village in Karanganyar Regency is proven to have built sustainability founded on environmental ethics and social entrepreneurship principles. The stages of realizing this sustainability began with raising community awareness by providing counselling about the importance of preserving the living environment and social entrepreneurship. This was followed by the stage of transformation of knowledge, by providing training to build entrepreneurial skills using the local potential that was in harmony with environmental balance, and the stage of providing mentoring for social entrepreneurship by optimizing local potential to build community independence, which was shown by the presence of an added economic value, the strengthening of social capital in the community, and the affirmation of institutional capacity. The principles of environmental ethics inspired the development of the language village in Karanganyar Regency, as shown in Table 1.

Table 1. Development of a language village based on principles of environmental ethics.

\begin{tabular}{|c|c|c|}
\hline $\begin{array}{l}\text { Principles of } \\
\text { Environmental } \\
\text { Ethics }\end{array}$ & Meaning & $\begin{array}{l}\text { Implementation in Development of Language } \\
\text { Tourism Village }\end{array}$ \\
\hline \multirow[t]{3}{*}{ Respect for Nature } & \multirow{3}{*}{$\begin{array}{l}\text { Nature has the right to be respected, } \\
\text { not only because human life depends } \\
\text { on nature but more because humans are } \\
\text { a part of the unity of nature itself }\end{array}$} & $\begin{array}{l}\text { Positioning the language tourism village as part of } \\
\text { the universe }\end{array}$ \\
\hline & & $\begin{array}{l}\text { Using a tree house as a reminder that human life and } \\
\text { trees become one in a bond with the universe }\end{array}$ \\
\hline & & $\begin{array}{l}\text { The tourism village does not alter the daily lives of } \\
\text { people working in the fields }\end{array}$ \\
\hline \multirow[t]{3}{*}{$\begin{array}{l}\text { Moral Responsibility } \\
\text { for Nature }\end{array}$} & \multirow{3}{*}{$\begin{array}{l}\text { Human beings, as part of the universe, } \\
\text { have a responsibility to preserve and } \\
\text { look after nature }\end{array}$} & $\begin{array}{l}\text { Building a camping ground that follows the contour } \\
\text { of the land }\end{array}$ \\
\hline & & $\begin{array}{l}\text { Carrying out reforestation on land prone to } \\
\text { landslides }\end{array}$ \\
\hline & & $\begin{array}{l}\text { Building a play area that retains the beauty of the } \\
\text { natural environment }\end{array}$ \\
\hline \multirow[t]{2}{*}{ Cosmic Solidarity } & \multirow{2}{*}{$\begin{array}{l}\text { Human beings can feel what other } \\
\text { living creatures in the universe feel }\end{array}$} & Continuing to preserve the balance of the ecosystem \\
\hline & & Not polluting the environment \\
\hline \multirow[t]{2}{*}{$\begin{array}{l}\text { Principle of Care and } \\
\text { Concern for Nature }\end{array}$} & \multirow{2}{*}{$\begin{array}{l}\text { The more care and concern people } \\
\text { have for nature, the more they will } \\
\text { develop into mature human beings with } \\
\text { a strong personalities and identity }\end{array}$} & $\begin{array}{l}\text { Planting various kinds of plants, both for agricultural } \\
\text { production and for aesthetic and conservation } \\
\text { purposes }\end{array}$ \\
\hline & & Holding nature-themed activities \\
\hline $\begin{array}{l}\text { Principle of "No } \\
\text { Harm" }\end{array}$ & $\begin{array}{l}\text { Human beings have a moral obligation } \\
\text { and responsibility towards nature and } \\
\text { should at least be committed to not }\end{array}$ & $\begin{array}{l}\text { Maintaining the topography of the land by not } \\
\text { destroying trees and not damaging the ecology of the } \\
\text { soil }\end{array}$ \\
\hline
\end{tabular}




\begin{tabular}{|l|l|l|}
\hline & harming nature & $\begin{array}{l}\text { Carrying out acts of care, protection, and } \\
\text { preservation of nature }\end{array}$ \\
\hline Principle of Living & $\begin{array}{l}\text { Importance of good values, qualities, } \\
\text { and way of life, not wealth or material } \\
\text { Simply and in } \\
\text { Harmony with }\end{array}$ & $\begin{array}{l}\text { Using nature only as needed for the benefit of the } \\
\text { local people }\end{array}$ \\
\cline { 3 - 3 } & $\begin{array}{l}\text { standards. Emphasis not on greed and } \\
\text { the desire to accumulate as much } \\
\text { property and wealth as possible but } \\
\text { more on the importance of good quality } \\
\text { of life }\end{array}$ & $\begin{array}{l}\text { Using water sources only as needed and for the } \\
\text { common interest of the community }\end{array}$ \\
\hline Principle of Justice & $\begin{array}{l}\text { The way people treat each other about } \\
\text { the universe, along with their social } \\
\text { systems, must be regulated to have a } \\
\text { positive impact on environmental } \\
\text { sustainability }\end{array}$ & $\begin{array}{l}\text { Adhering to an unwritten agreement that when } \\
\text { chopping down trees, new plants of a similar kind } \\
\text { must be grown in their place }\end{array}$ \\
\cline { 3 - 3 } & $\begin{array}{l}\text { Continuing to encourage the planting of trees at the } \\
\text { roadside to preserve the balance of nature }\end{array}$ \\
\hline
\end{tabular}

Data source: analysis of primary data through in-depth interviews.

The community The community was involved as the party that had the right to formulate the development plan for the tourism village, which included determining the goals, compiling the programs and planned activities, and designing a budget plan. This direct involvement of the community in the tourism village development process was important for the following reasons. First, it accommodated the wishes and demands of the community, namely that the development of the tourism village should be based on people's desire to develop the existing potential in their village as a medium for improving community welfare, so community involvement aimed to ensure that the development of the tourism village was in line with their wishes and demands. Second, encouraging the participation of the community in the development process aimed to arouse a sense of community ownership for the tourism village potential being developed so that they would have a desire to become more involved and feel a sense of belonging to the tourism village development. Third, it served as a medium for the community to grow and strengthen the existing community institution because joint involvement in the development of the tourism village would increase people's understanding and capacity to develop their potential, creating a strong community institution.

Social entrepreneurship was the next inspiration for stakeholders in empowering the community in line with the development of the language tourism village. Social entrepreneurs view problems as opportunities to form a new business model that empowers the surrounding community. Social entrepreneurship is the utilization of entrepreneurial behaviour oriented more towards achieving social goals rather than prioritizing profit or towards the use of profit for social purposes [52]. Table 2 below shows the implementation of the language tourism village development based on social entrepreneurship.

Table 2. Development of a language tourism village based on social entrepreneurship.

\begin{tabular}{|l|l|l|}
\hline $\begin{array}{c}\text { Entrepreneurship } \\
\text { Component }\end{array}$ & \multicolumn{1}{|c|}{ Meaning } & \multicolumn{1}{|c|}{$\begin{array}{c}\text { Implementation in Development of Language Tourism } \\
\text { Village }\end{array}$} \\
\hline Resources & $\begin{array}{l}\text { Resources are the main asset in a } \\
\text { business enterprise }\end{array}$ & $\begin{array}{l}\text { Leaders of the Islamic boarding school who play a role as } \\
\text { agents of change optimize all resources for the language } \\
\text { tourism village development }\end{array}$ \\
\hline Networking & $\begin{array}{l}\text { Possessing and optimizing } \\
\text { networking resources to } \\
\text { accelerate the business enterprise } \\
\text { being developed }\end{array}$ & $\begin{array}{l}\text { The Islamic boarding school helps build synergy between } \\
\text { three nearby villages to synergize and develop a network } \\
\text { that helps each other grow and is mutually beneficial }\end{array}$ \\
\hline $\begin{array}{l}\text { Research and } \\
\text { Development }\end{array}$ & $\begin{array}{l}\text { Research and development is an } \\
\text { essential aspect for building trust } \\
\text { in innovation and increasing } \\
\text { competitiveness and credibility }\end{array}$ & $\begin{array}{l}\text { Before carrying out a large-scale business, a trial is carried } \\
\text { out on a smaller scale to test whether the business matches } \\
\text { the consumer's wishes or the customer. }\end{array}$ \\
\hline $\begin{array}{l}\text { Packaging, } \\
\text { Marketing, and }\end{array}$ & $\begin{array}{l}\text { Building character and relations } \\
\text { Branding }\end{array}$ & $\begin{array}{l}\text { The character built emphasizes the existence of the language } \\
\text { tourism village as the first of its kind in Central Java } \\
\text { province and promotes its character as a language tourism } \\
\text { village that synergizes with an Islamic boarding school in } \\
\text { deepening its religious knowledge }\end{array}$ \\
\hline $\begin{array}{l}\text { Leadership and } \\
\text { Entrepreneurship }\end{array}$ & $\begin{array}{l}\text { Management speaks about } \\
\text { function while leadership speaks } \\
\text { about relations }\end{array}$ & $\begin{array}{l}\text { Creating a balance between the functions of business } \\
\text { management by motivating members of the community to } \\
\text { have a more extraordinary passion for developing their own } \\
\text { potential }\end{array}$ \\
\hline
\end{tabular}

Data source: analysis of primary data through in-depth interviews 
keys to social entrepreneurship: the presence of social innovation that can change the existing system of a community and the presence of individuals with vision, creativity, an entrepreneurial spirit, and good ethics behind these innovative ideas [53]. The presence of Isy Karima Islamic boarding school fulfils both these key criteria. It offers a social innovation in religious tourism and provides human resources committed to becoming facilitators in empowering the local community. This social entrepreneurship plays a vital role in empowering the local community, in line with the research results of [54-56], namely that efforts to solve social problems by using an entrepreneurship approach provide an effective solution for eradicating poverty in a country. In addition, [57] explains that social entrepreneurship is a dynamic process created and managed by an individual or team that tries to use social innovation with an entrepreneurial thought pattern for creating new social value in the market and community. This has proven to be the case in the language tourism village in Karanganyar Regency, where the development of the language tourism village has had the following impacts: created job opportunities, reduced unemployment, increased income, combined factors of production (nature, labour, assets, and expertise), and raised productivity.

In connection with this, the Islamic boarding school is proven to have the ability to implement development in the surrounding community. The implementation of social entrepreneurship integrated with principles of environmental ethics, which is indicated by the strengthening of networking relations, leads to sustainability of the language tourism village, as shown in figure 1 below.

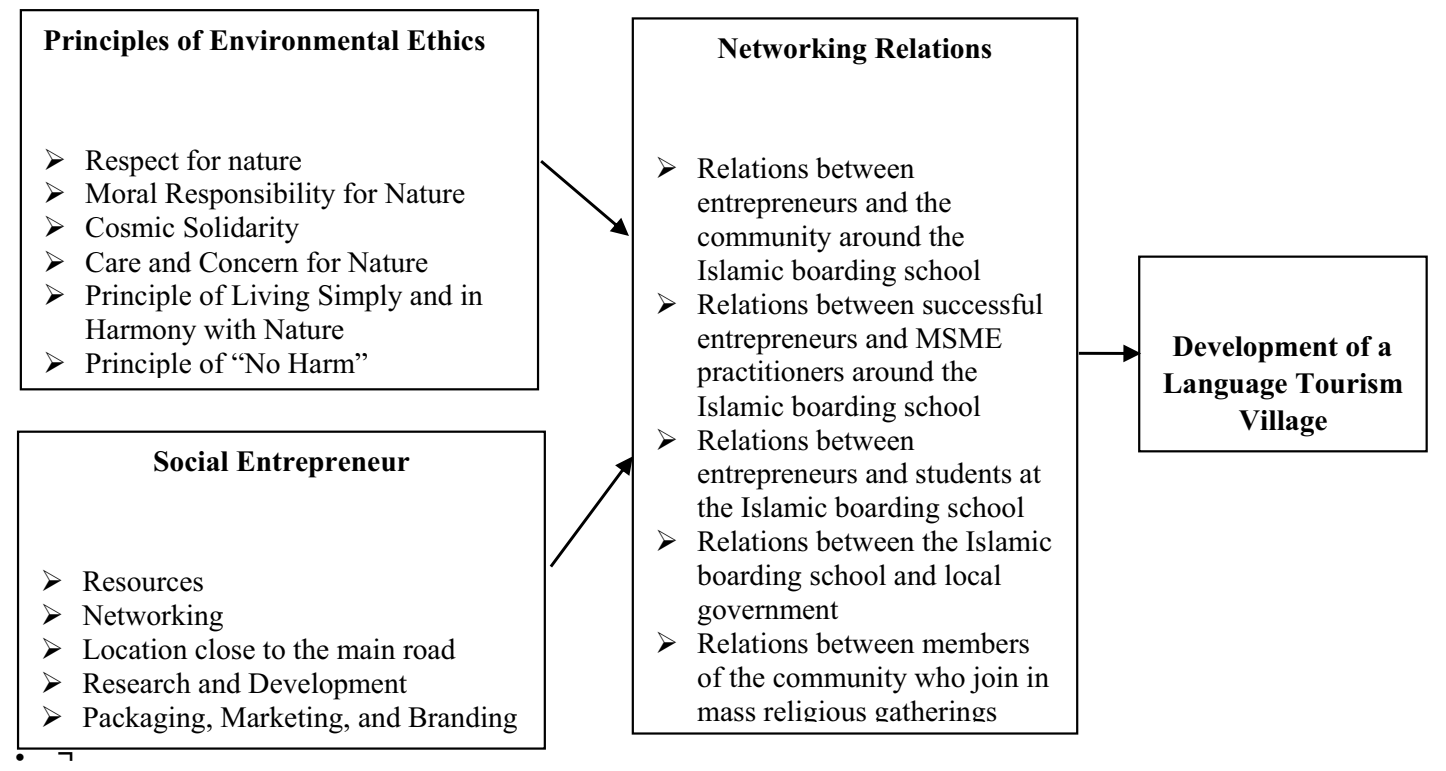

Fig 1. Model of Development of a Language Tourism Village Based on

\section{Conclusion} Environmental Ethics and Social Entrepreneurship

The language The language tourism village in Karanganyar Regency plays a vital role because: (1) it accommodates the wishes and demands of the community, (2) it encourages community participation in the development process, where community involvement aims to arouse a sense of community ownership for the tourism village potential being developed, and (3) it serves as a medium for the community to grow and strengthen the existing community institution. The model of developing a language tourism village based on principles of environmental ethics and social entrepreneurship has been proven to contribute to the success of developing village tourism. Environmental ethics inspire stakeholders to preserve the environment, while social entrepreneurship serves as inspiration for empowering the surrounding community.

\section{Reference}

1. 1. Anggraini, Nenny. 2018. Industri Kreatif. Jurnal Ekonomi, 13(3): 142-146

2. 2. Sari, A. P., Pelu, M. F. A., Dewi, I. K., Ismail, M., Siregar, R. T., Mistriani, N., \& Sudarmanto, E. (2020). Ekonomi Kreatif. Yayasan Kita Menulis.

3. 3. Wicaksono, F., Risda, D., \& Landarica, B. A. (2020, December). Collaborative Governance in The Framework of Community Empowerment Through Creative Economy. in Conference Proceeding One Asia 2 (Vol. 1, No. 1, pp. 65-69).

4. 4. Purbasari, R., Wijaya, C., \& Rahayu, N. (2019). Entrepreneurial ecosystem and regional competitive 
advantage: A case study on the creative economy of Indonesia. Advances in Social Sciences Research Journal, 6(6), 92-110.

5. 5. Ukkas, Imran. 2017. Faktor-Faktor yang Mempengaruhi Produktivitas Tenaga Kerja Industri Kecil Kota Palopo. Jurnal of Islamic Education Management, 2(2): 187-198

6. 6. Cioruța, B., Coman, M., Lauran, A., \& Cioruta, A. A. (2018). From Human-Environment Interaction to Environmental Informatics (I): Theoretical and Practical Implications of Knowledge-based Computing.

7. 7. Nasibulina, A. (2015). Education for sustainable development and environmental ethics. Procedia-Social and Behavioral Sciences, 214, 1077-1082.

8. 8. Palmer, C., McShane, K., \& Sandler, R. (2014). Environmental ethics. Annual Review of Environment and Resources, 39, 419-442.

9. 9. Mair, J., Robinson, J., \& Hockerts, K. (Eds.). (2006). Social entrepreneurship (Vol. 3). New York: Palgrave Macmillan.

10. 10. Nicholls, A. (Ed.). (2008). Social entrepreneurship: New models of sustainable social change. OUP Oxford.

11. 11. Dodds, R., Ali, A., \& Galaski, K. (2016). Key elements of success and barriers in community based tourism. Current Issues in Tourism DOI, 10(13683500.2016), 1150257.

12. 12. Kenny, Sue, Azwar Hasan, dan Ismet Fanany. 2017. The Backdrop: The Discourse and Practice of Community Development in Indonesia. Community Development Journal. 52(1) : 107-124

13. 13. Eimermann, Marco., Agnidakis, Paul., Akerlund, Ulrika and Woube, Annie. 2017. Rural Place Marketing and Consumtion-Driven Mobielities in Northern Sweden: Challenges and Opportunities for Community Sustainability. International Journal of Rural and Community Development., 12(2) : 114-126

14. 14. Cavaye, J and Ross, H. 2019. Community Resilience and Community Development: What Mutual Opportunities Aries from Interactions Between the Two Concepts? Journal Community Development. 50(2): 181-200.

15. 15. Muhyidin, Deden S, Ali A. 2017. Pemberdayaan masyarakat melalui program inovasi pembangunan dan pemberdayaan kewilayahan. Jurnal Pengembangan Masyarakat Islam 2(2): 59-79.

16. 16. Mathambo, M Kistler. 2017. Contiguous community development. J of Rural Studies 5(1): 83-92.

17. 17. Elias, Renee Roy., dan Alison Moore. 2017. The Evolution and Future of The Healthy Communities Movement. Community Development Innovation Review, 45(2): 345-367.

18. 18. Aquino, R. S., Lück, M., \& Schänzel, H. A. (2018). A conceptual framework of tourism social entrepreneurship for sustainable community development. Journal of Hospitality and Tourism Management, 37, 23-32.

19. 19. De Lange, D., \& Dodds, R. (2017). Increasing sustainable tourism through social entrepreneurship. International Journal of Contemporary Hospitality Management.

20. 20. Sheldon, P. J., Pollock, A., \& Daniele, R. (2017). Social entrepreneurship and tourism: Setting the stage. In Social Entrepreneurship and Tourism (pp. 1-18). Springer, Cham.

21. 21. Farrel, Henry O. 2020. Development in Online, Social Media Marketing in China and the West: An Overview of Different Approaches. Journal of Entrepreneuship and Inovation in Emrging Economies, 6(2): 383-403

22. 22. Pandjaitan, R. H., \& Dewi, I. R. (2021). The Influence of Teachers' Approaching Obstacle on the Adoption Technological Innovation within the Electric Vehicle among the Vocational High School Educations. Psychology and Education Journal, 58(2), 6058-6071.

23. 23. Merrilees, Miller and Herington. 2018. Antecedents of Residents`City Brand Attitudes. Journal of Business Research, 6(2): 135-141.

24. 24. Agustina, Y., Winarno, A., Pratikto, H., Narmaditya, B. S., \& Filianti, F. (2020). A Creative Economy Development Strategy: The Case of Trenggalek Creative Network for Trenggalek Regency, Indonesia. The Journal of Asian Finance, Economics, and Business, 7(12), -1122.

25. 25. Dudek-Mańkowska, S., \& Grochowski, M. (2019). From creative industries to the creative place brand: some reflections on city branding in Poland. Place 1111Branding and Public Diplomacy, 15(4), 274-287.

26. 26. Dewi, Rany P dan Arnandi, Wandi. 2019. Peningkatan Produktivitas Peternak Itik Melalui Penerapan Mesin Penetas Telur. Jurnal Pengabdian dan Pemberdayaan Masyarakat, 3(2): 193-196.

27. 27. Fusco Girard, L., \& Vecco, M. (2021). The "Intrinsic Value" of Cultural Heritage as Driver for Circular Human-Centered Adaptive Reuse. Sustainability, 13(6), 3231.

28. 28. Kimberlee, L. 2019. The Impact of Leadership on Organizational Performance. Journal of Research and Applied Science, 2(4): 207-216.

29. 29. Yuldinawati, L., Tricahyono, D., Anggadwita, G., and Alamanda, D. T. 2018. Towards a Framework for ICT-Based Entrepreneurship Development through Business Incubation Processes: Case Study of a Techno Park. International Journal of Business and Globalisation, 21(1): 1-14.

30. 30. Ngibe, Musawenkosi., Lekhanya, Lawrence and Garbharran, Hari. 2019. Innovative Leadership Characteristics of Manufacturing SMEs in kwazulu-Natal. International Journal of Entrepreneurship, 23(4): 1-12.

31. 31. Zamakhsyari, Dhofier. 1983. Tradisi Pesantren Studi tentang Pandangan Hidup Kyai. Jakarta: LP3S.

32. 32. Schutte, De Wet. 2017. Community Development and Community Participant Conceptual Revisit. Journal of Community Development, 54(2): 173-178.

33. 33. Koeswantono, Sri. 2018. Pemberdayaan Masyarakat Melalui Pelatihan Menyulam pada Ibu-Ibu di Desa 
Pabuaran Kecamatan Suka Makmur Kabupaten Bogor. Jurnal Sarwahita, 11(2): 82- 86.

34. 34. Allen, N. J., \& Meyer, J. P. 2017. The Measurement and Antecedents of Affective, Continuance and Normative Commitment to The Organizaytion. Journal of Occupational Psychology, 63: 1-18.

35. 35. Omnbongi, P.N., and Long, W. 2018. Factors Affecting Financial Performance of Small and Medium Enterprises (SMEs): A Case of Manufacturing SMEs in Kenya. International Journal of Research in Business Studies and Management, 5(1): 37-45.

36. 36. Paredes, F., Flores, D., Figueroa, A., Gaymer, C. F., \& Aburto, J. A. (2019). Science, capacity building and conservation knowledge: the empowerment of the local community for marine conservation in Rapa Nui. Aquatic Conservation: Marine and Freshwater Ecosystems, 29, 130-137.

37. 37. Khalid, S., Ahmad, M. S., Ramayah, T., Hwang, J., \& Kim, I. (2019). Community empowerment and sustainable tourism development: The mediating role of community support for tourism. Sustainability, 11(22), 6248 .

38. 38. Ismanto, Deny. 2020. Pelatihan dan Pendampingan Santripreneur Berbasis Investasi Syariah Pondok Pesantren Se-Kecamatan Galur, Kabupaten Kulonprogo. Jurnal Karya Abadi, 4(1): 69-72.

39. 39. Keegan, S. (2009). Qualitative research: Good decision making through understanding people, cultures and markets. Kogan Page Publishers.

40. 40. Lamont, M., \& Swidler, A. (2014). Methodological pluralism and the possibilities and limits of interviewing. Qualitative Sociology, 37(2), 153-171.

41. 41. Van Velsen, J. (1979). The extended-case method and situational analysis. In The craft of social anthropology (pp. 129-149). Pergamon.

42. 42. Yin, R. K. (2011). Applications of case study research. sage.

43. 43. Sutopo, H. B. Metodologi Penelitian Kualitatif, dasar Teori dan Terapannya Dalam Penelitian. 2002. Surakarta: UNS.

44. 44. Creswell, J. W., \& Poth, C. N. (2016). Qualitative inquiry and research design: Choosing among five approaches. Sage publications.

45. 45. Bogdan, R., \& Biklen, S. K. (1997). Qualitative research for education. Boston, MA: Allyn \& Bacon.

46. 46. Anggito, A., \& Setiawan, J. (2018). Metodologi penelitian kualitatif. CV Jejak (Jejak Publisher).

47. 47. Cooper, J., Lewis, R., \& Urquhart, C. (2004). Using participant or non-participant observation to explain information behaviour. Information Research, 9-4.

48. 48. Ciesielska, M., Boström, K. W., \& Öhlander, M. (2018). Observation methods. In Qualitative methodologies in organization studies (pp. 33-52). Palgrave Macmillan, Cham.

49. 49. Miles, M. B., \& Huberman, A. M. (1994). Qualitative data analysis: An expanded sourcebook. sage.

50. 50. Ruona, W. E. (2005). Analyzing qualitative data. Research in organizations: Foundations and methods of inquiry, 223, 263.

51. 51. Setyawan, F. E. B. (2017). Pengantar Metodologi Penelitian:(Statistika Praktis). Zifatama Jawara.

52. 52. Hibbert, S. A., Hogg, G., \& Quinn, T. (2005). Social entrepreneurship: Understanding consumer motives for buying The Big Issue. Journal of Consumer Behaviour: An International Research Review, 4(3), 159-172.

53. 53. Hulgård, L. (2010). Discourses of social entrepreneurship-Variations of the same theme. EMES European Research Network, 10(1), 2-21.

54. 54. Sofia, I. P. (2017). Konstruksi Model Kewirausahaan Sosial (Social Entrepreneurship) sebagai gagasan inovasi sosial bagi pembangunan perekonomian. WIDYAKALA: JOURNAL OF PEMBANGUNAN JAYA UNIVERSITY, 2(1), 2-23.

55. 55. Jadmiko, P. (2019). Peran Pemediasi Attitude Becoming Social Entrepreneur (Atb) Pada Pengaruh Antara Empati Terhadap Minat Berwirausaha Sosial. Jurnal Benefita, 4(3), 422-434.

56. 56. Wuryandani, D., Harefa, M., Hilma Meilani, S. T., Mangeswuri, D. R., \& Silalahi, S. A. F. (2019). Pengembangan kewirausahaan untuk pemberdayaan UKM daerah. Yayasan Pustaka Obor Indonesia.

57. 57. Maulida, Y. (2018). Efektivitas Program Inovasi Desa Dalam Rangka Mewujudkan Kemandirian Desa Pada Dinas Pemberdayaan Masyarakat Desa Kabupaten Langkat. 